\title{
Pengaruh Campuran Pasir dan Serat Aren pada Kailan (Brassica oleraceae) dengan Hidroponik Substrat
}

\section{Effect of Sand and Wood Fiber Waste of Arenga Mixture towards Kailan (Brassica oleraceae) on Hydroponics Substrate}

\author{
Riandy Adhitya ${ }^{1)}$, Samanhudi ${ }^{2)}$, Dwi Harjoko ${ }^{2)}$
}

\begin{abstract}
Wood fiber waste of arenga produced from starch palm industry. It is not handled properly so that could be potentially cause problems for the surrounding community. Wood fiber waste of arenga is potentially used as a medium for hydroponics. The waste can be utilized to get a new composition of hydroponic media. This study aims to determine the effect of a mixture of sand with arenga fiber waste.This research was carried out by using a mixture of sand and arenga wood fiber waste as a medium. This is an experimental study using a completely randomized design. This study aims to determine the effect of a mixture of sand and arenga fiber waste for kailan growth. The results showed that the mixture of sand and arenga wood fiber waste has no effect on kailan growth. The combination of mixtures of sand and arenga fiber waste showed no interaction. Observations on plants such as plant height, number of leaves, leaf greenness levels, the fresh weight of crop stover and stover dry weight of the plant, showed a row of the highest results in the media mix washed sand, washed sand and rice husk.
\end{abstract}

Keywords : kailan, arenga wood fiber, sand, mixture

\section{PENDAHULUAN}

Aren (Arenga pinnata) merupakan tumbuhan berbiji tertutup dimana biji buahnya terbungkus daging buah. Tepung aren dapat digunakan untuk pembuatan aneka produk makanan, sampai saat ini tepung dari pati batang aren belum dapat disubstitusi (Saleh 2011). Menurut Firdayati (2005) Limbah serat yang tidak ditangani dengan baik, berpotensi menimbulkan masalah bagi komunitas sekitarnya. Limbah serat yang komponen dasarnya ada materi organik akan terdekomposisi secara alamiah di lingkungan. Namun dalam prosesnya sering sekali timbul gangguan bau dan estetika dari timbunan limbah serat ini. Limbah serat yang masih mengandung pati dan dalam keadaan lembab, diketahui kadang ditumbuhi beberapa jenis jamur, sehingga dalam tiga tahun terakhir, limbah tersebut diambil oleh sebuah perusahaan jamur. Ini cukup mengurangi namun belum mampu menyerap limbah serat yang ada.

Kailan (Brassica oleraceae) berasal dari Negeri Cina. Kailan merupakan jenis sayuran baru di Indonesia, tetapi telah menjadi kegemaran keluarga. Bentuk tanaman kailan sepintas lalu mirip dengan sawi/caisim atau kembang kol. Daunnya panjang dan melebar seperti caisim, sedangkan warna daun dan batangnya mirip dengan kembang kol. Batangnya

\footnotetext{
1) Undergraduate Student of Study Program of Agrotechnology, Faculty of Agriculture, Sebelas Maret University.

2) Lecturer of Study Program of Agrotechnology, Faculty of Agriculture, Sebelas Maret University.
}

agak manis dan empuk di lidah. Sedangkan daunnya enak dan legit (Tyndall 1986).

Jumlah penduduk Indonesia yang semakin bertambah serta meningkatnya kesadaran akan kebutuhan gizi yang menyebabkan bertambahnya permintaan sayuran. Untuk memenuhi permintaan yang tinggi tersebut ditambah peluang pasar internasional yang cukup besar bagi kailan layak diusahakan ditinjau dari aspek ekonomi atau bisnis (Haryanto et al. 2002). Media pasir sering digunakan dalam hidroponik sebagai media. Penggunaan pasir sebagai media tanam sering dikombinasikan dengan campuran media hidroponik yang lain. Bahan baku media biasanya digunakan mengacu pada ketersediaan lokal. Bahan baku tersebut dapat berupa organik maupun anorganik, tetapi pembuatan media tanam sering menggunakan campuran dari bahan yang berbeda untuk mencapai keseimbangan udara dan kemampuan menahan air selama masa pertanaman dan juga untuk stabilitas media jangka panjang (Nair 2011). Berdasarkan hal tersebut, maka campuran antara serat aren dengan pasir diharapkan mendukung pertumbuhan kailan.

\section{METODE PENELITIAN}

Penelitian ini dilaksanakan pada bulan Juli 2013 sampai September 2013 di Rumah Kaca B Fakultas Pertanian Universitas Sebelas Maret Surakarta. Analisis laboratorium di Laboratorium Ekologi Manajemen Produksi Tanaman Fakultas Pertanian Universitas Sebelas Maret Surakarta. Bahan yang digunakan dalam penelitian ini meliputi benih kailan, limbah serat aren, nutrisi $A B$ mix, air, pasir merapi tidak dicuci, pasir merapi dicuci, arang sekam dan fungisida. Alat-alat yang digunakan untuk penelitian

Contact Author: samanhudi@uns.ac.id

Pengaruh Campuran Pasir dan Serat Aren pada Kailan (Brassica oleraceae)

Riandy Adhitya, Samanhudi, Dwi Harjoko 
ini yaitu tray (tempat pembibitan), gelas ukur, sprayer, alat tulis, dan penggaris.

Perancangan penelitian disusun berdasarkan rancangan acak lengkap (RAL) dengan faktor pertama adalah limbah serat aren yang terdiri dari tiga taraf yaitu limbah serat aren direndam fungisida, limbah serat aren direndam air selama enam hari, dan limbah serat aren disterilisasi, faktor kedua adalah media substrat yang terdiri dari tiga taraf yaitu pasir dicuci, pasir tidak dicuci, dan arang sekam, masingmasing perlakuan diulang empat kali.

Tahap-tahap pelaksanaan penelitian meliputi pembuatan konstruksi, pembibitan, penyiapan media, penanaman, penyiraman, pemupukan, penyulaman, pemeliharaan, pemanenan. Pengamatan penelitian meliputi tinggi tanaman, jumlah daun, kadar kehijauan daun, panjang akar, berat brangkasan segar tanaman, dan berat brangkasan kering tanaman. Data hasil pengamatan dianalisis dengan uji $\mathrm{F}$ pada taraf 5\% dilanjutkan dengan uji Duncan Multiple Range Test (DMRT) taraf 5\%.

\section{HASIL DAN PEMBAHASAN}

\section{Tinggi Tanaman}

Tinggi tanaman merupakan ukuran tanaman yang paling sering diamati baik sebagai indikator pertumbuhan maupun sebagai parameter yang digunakan untuk mengukur pengaruh lingkungan atau perlakuan yang diterapkan. Pengaruh perlakuan campuran media serat aren dengan substrat terhadap tinggi tanaman selama sepuluh minggu disajikan pada Gambar 1.
Gambar 1 menunjukkan campuran serat aren dengan media pasir mendominasi tinggi tanaman kailan. Hal ini menunjukkan bahwa campuran pasir dengan serat kayu aren lebih baik daripada campuran dengan arang sekam. Hal ini dapat dilihat dari tiga campuran yang mempunyai nilai tertinggi yaitu campuran serat aren rendam air 6 hari dengan pasir dicuci, campuran serat aren rendam air 6 hari dengan pasir tidak dicuci, dan campuran serat aren sterilisasi autoklaf dengan pasir tidak dicuci. Pasir yang memiliki sifat sifat berpori besar (pori-pori makro) sehingga pasir menjadi mudah basah dan cepat kering oleh proses penguapan menjadi media yang lebih baik daripada arang sekam. Ini diperkuat oleh Siregar (2000) perbaikan sifat fisik tanah sebagai akibat dari penambahan bahan organik dapat meningkatkan daya sangga air, agregasi, permeabilitas dan aerasi tanah. Pada campuran media arang sekam dengan serat aren yang terjadi ialah pelapukan yang menjadikan sifat fisik arang sekam dan serat aren menjadi terganggu, menyusutan massa media dan ketebalan media juga menjadi penyebab rendahnya tinggi tanaman pada campuran serat aren dengan arang sekam. Banyak penelitian yang mengindikasikan keuntungan dari pencampuran media tanam organik dan anorganik untuk sayuran dengan peningkatan kinerja dalam produksi rumah kaca (Tzortzakis 2008). Komponen organik terurai selama produksi tanaman dan dapat berubah baik secara fisik maupun kimia (Bilderback 2005).

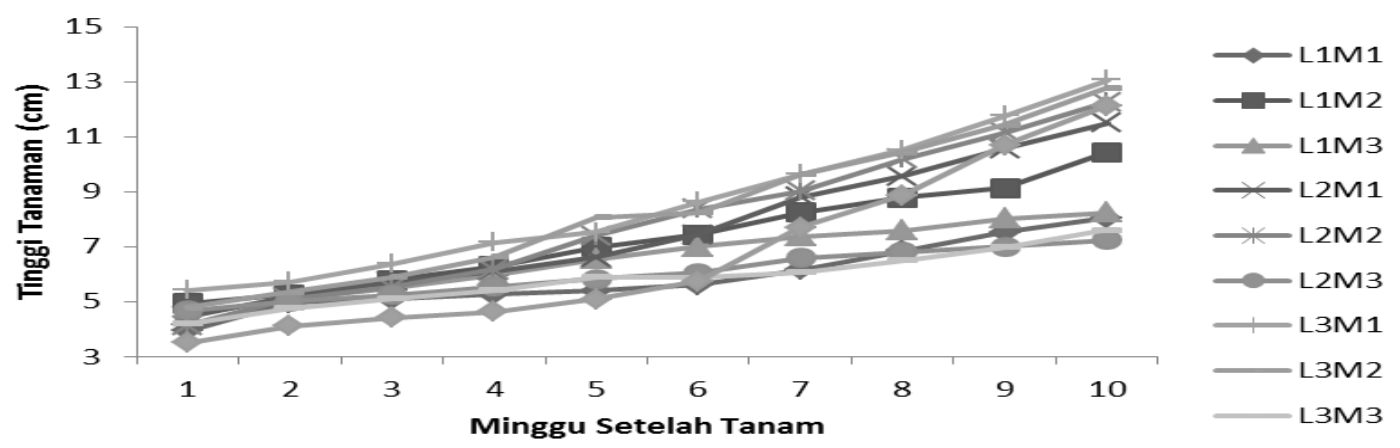

Keterangan:

L1M1 = Campuran serat aren rendam larutan fungisida dengan pasir dicuci

$\mathrm{L} 1 \mathrm{M} 2$ = Campuran serat aren rendam larutan fungisida dengan pasir tidak dicuci

$\mathrm{L} 1 \mathrm{M} 3=$ Campuran serat aren rendam larutan fungisida dengan arang sekam

L2M1 = Campuran serat aren sterilisasi autoklaf dengan pasir dicuci

L2M2 = Campuran serat aren sterilisasi autoklaf dengan pasir tidak dicuci

L2M3 = Campuran serat aren sterilisasi autoklaf dengan arang sekam

L3M1 = Campuran serat aren rendam air 6 hari dengan pasir dicuci

L3M2 = Campuran serat aren rendam air 6 hari dengan pasir tidak dicuci

L3M3 = Campuran serat aren rendam air 6 hari dengan arang sekam

Gambar 1. Tinggi tanaman kalian pada beberapa minggu setelah tanam

\section{Jumlah Daun}

Daun merupakan organ tanaman tempat mensintesis makanan untuk kebutuhan tanaman maupun sebagai cadangan makanan. Daun memiliki klorofil yang berperan dalam melakukan fotosintesis.
Semakin banyak jumlah daun, maka tempat untuk melakukan fotosintesis lebih banyak dan hasilnya lebih banyak juga (Gardner et al. 1991). Rerata jumlah daun umur 10 MST disajikan pada tabel 1. 
Tabel 1. Rerata jumlah daun umur 10 MST dengan beberapa perlakuan media

\begin{tabular}{lllll}
\hline \multirow{2}{*}{ Substrat } & \multicolumn{3}{c}{ Jumlah Daun (helai) } & \multirow{2}{*}{ Rerata } \\
\cline { 2 - 4 } & Pasir Dicuci & Pasir Tidak Dicuci & Arang Sekam & \\
\hline Rendam larutan fungisida & 3,63 & 5,38 & 4,63 & $4,54 \mathrm{a}$ \\
Sterilisasi autoklaf & 6,88 & 6,63 & 4,13 & $5,88 \mathrm{~b}$ \\
Rendam air enam hari & 7,13 & 7,25 & 4,38 & $6,25 \mathrm{~b}$ \\
\hline Rerata & $5,88 \mathrm{~b}$ & $6,42 \mathrm{~b}$ & $4,38 \mathrm{a}$ &
\end{tabular}

Keterangan : Nilai yang diikuti huruf beda pada kolom atau baris yang sama menunjukkan berpengaruh nyata pada Uji DMRT taraf $5 \%$.

Serat kayu aren pada awal penanaman memiliki sifat yang keras dan padat sehingga dapat mengurangi kemampuan media tanam dalam menyediakan unsur hara yang mengakibatkan jumlah daun yang dihasilkan tidak maksimal hingga pertengahan penanaman. Sifat keras dan sulit untuk dicampur dari serat aren ini mempengaruhi perbedaan campuran media yang digunakan. Pada campuran pasir dicuci maupun tidak dicuci, serat dapat tercampur dan memadat karena pasir mempunyai massa yang berat dibandingkan dengan arang sekam. Massa arang sekam yang ringan membuat arang sekam dan serat aren sulit untuk memadat sehingga membuat ronggarongga didalam media sehingga kandungan air lebih cepat menguap. Pertumbuhan jumlah daun tanaman kalian ini juga dipengaruhi oleh jamur yang tumbuh di media tanam. Ini disebabkan oleh media serat aren yang bersifat bahan organik yang mudah lapuk dan cocok menjadi tempat tumbuhnya jamur yang menempel pada daun tanaman kailan bila mati. Menurut Alexander (1997) Fungi terdapat di setiap tempat terutama di darat dalam berbagai bentuk, ukuran, dan warna. Pada umumnya mempunyai kemampuan yang lebih baik dibanding bakteri dalam mengurai sisa-sisa tanaman (hemiselulosa, selulosa, dan lignin). Umumnya mikroba yang mampu mendegradasi selulosa juga mampu mendegradasi hemiselulosa.

Hasil pengamatan menunjukkan serat aren rendam enam hari mempunyai rerata jumlah daun yang paling tinggi yaitu 6,25 helai lalu diikuti oleh serat aren sterilisasi 5,88 helai dan yang terkecil yaitu rendam fungisida sebesar 4,54 helai. Ini menunjukkan perlakuan berbedaan jenis media dan rendaman serat mempunyai pengaruh berbeda nyata terhadap jumlah daun tanaman kailan. Hal ini disebabkan karena serat aren yang telah disterilisasi mengalami perubahan fisik menjadi lebih lunak karena perlakuan panas dan tekanan tinggi pada autoklaf. Pada serat aren rendam air enam hari diduga telah mengalami pelapukan oleh bakteri selama perndaman tersebut sehingga sifat fisik menjadi lebih lunak dibandingkan serat aren rendam fungisida.

\section{Kadar Kehijauan Daun}

Klorofil banyak terdapat di daun dan bagian tanaman lainnya dengan karakteristik berwarna hijau dan berperan dalam fotosintesis tanaman. Klorofil berada dalam kloroplas, tempat berlangsungnya fotosintesis. Pigmen-pigmen yang terdapat di dalam membran tilakoid akan menyerap cahaya yang berasal dari matahari atau sumber lain, kemudian mengubah energi cahaya menjadi energi kimia dalam bentuk adenosin trifosfat (ATP). Semakin banyak kandungan klorofil maka kemungkinan terjadinya fotosintesis akan berjalan lebih cepat sehingga fotosintat yang dihasilkan lebih tinggi. Fotosintat digunakan untuk memenuhi kebutuhan tanaman, pertumbuhan, serta sebagai cadangan makanan (Lakitan 2004). Rerata kadar kehijauan daun umur 10 MST disajikan pada Tabel 2.

Tabel 2. Rerata kadar kehijauan daun umur 10 MST pada beberapa perlakuan media

\begin{tabular}{lllll}
\hline \multirow{2}{*}{ Substrat } & \multicolumn{3}{c}{ Kadar Kehijauan Daun } & \multirow{2}{*}{ Rerata } \\
\cline { 2 - 4 } & Pasir Dicuci & Pasir Tidak Dicuci & Arang Sekam & \\
\hline Rendam larutan & 37,61 & 59,65 & 41,54 & $46,26 \mathrm{a}$ \\
fungisida & 54,7 & 54,88 & 36,72 & $48,77 \mathrm{a}$ \\
Sterilisasi autoklaf & 53,68 & 42,41 & $47,74 \mathrm{a}$ \\
Rendam air enam hari & 47,14 & $56,07 \mathrm{~b}$ & $40,22 \mathrm{a}$ & \\
\hline Rerata & $46,48 \mathrm{a}$ & & \\
\hline
\end{tabular}

Keterangan: Nilai yang diikuti huruf beda pada kolom atau baris yang sama menunjukkan berpengaruh nyata pada Uji DMRT taraf $5 \%$.

Pada perlakuan jenis media, kadar kehijauan daun yang dicapai pada umur 10 MST berbeda. Dari tabel rerata kadar kehijauan daun (tabel 3) dapat dilihat bahwa rerata perlakuan tertinggi adalah jenis media pasir tidak dicuci yaitu sebesar 56,07 kemudian diikuti perlakuan pasir dicuci sebesar $46,48 \mathrm{~cm}$, dan rerata kadar kehijauan daun paling rendah adalah arang sekam yaitu sebesar 40,22 cm. Ini menunjukkan perlakuan perbedaan jenis media mempunyai efek berbeda terhadap kadar kehijauan daun kailan. 
Kadar kehijauan daun sangat erat hubungannya dengan fotosintesis, kadar kehijauan daun yang tinggi menunjukkan proses fotosintesis yang cepat dan optimal sehingga fotosintesis yang cepat mempengaruhi variabel pertumbuhan yang lain.

\section{Panjang Akar Tanaman}

Akar merupakan bagian tanaman yang langsung berhubungan dengan tanah, salah satu bagian vital yang berperan dalam pertumbuhan dan kelangsungan hidup tanaman dengan jalan mengabsorpsi hara dan air, disamping itu akar merupakan bagian tanaman yang berfungsi untuk menegakkan dan berdirinya tanaman (Syarief, 1988). Menurut Doorenbos et al. (1979) air dan nutrisi pada tanaman merupakan sesuatu yang tidak dapat dipisahkan, karena nutrisi yang dibutuhkan oleh tanaman akan diserap oleh akar alam bentuk nutrisi yang sudah terlarut dalam air. Umumnya akar pada kultur budidaya tanpa tanah biasanya terkena variasi temperatur yang besar sehingga akar tanaman dapat selamat dari suhu akar ekstrim yang panas dan dingin (Kafkafi 2001). Rerata panjang akar umur 10 MST disajikan pada tabel 3.

Tabel 3. Rerata panjang akar umur 10 MST pada beberapa perlakuan media

\begin{tabular}{lllll}
\hline \multirow{2}{*}{ Substrat } & \multicolumn{3}{c}{ Panjang Akar (cm) } & \multirow{2}{*}{ Rerata } \\
\cline { 2 - 4 } & Pasir Dicuci & Pasir Tidak Dicuci & Arang Sekam & \\
\hline Rendam larutan fungisida & 10,98 & 8,35 & 14,15 & $11,16 \mathrm{a}$ \\
Sterilisasi autoklaf & 13,25 & 11,15 & 10,45 & $11,62 \mathrm{a}$ \\
Rendam air enam hari & 15,04 & 10,53 & 13,31 & $12,96 \mathrm{a}$ \\
\hline Rerata & $13,09 \mathrm{a}$ & $10,01 \mathrm{a}$ & $12,64 \mathrm{a}$ \\
\hline
\end{tabular}

Keterangan: Nilai yang diikuti huruf beda pada kolom atau baris yang sama menunjukkan berpengaruh nyata pada Uji DMRT taraf $5 \%$.

Pada perlakuan jenis media, panjang akar yang dicapai pada umur 10 MST berbeda. Dari tabel rerata panjang akar (Tabel 3) dapat dilihat bahwa rerata perlakuan tertinggi adalah jenis media pasir dicuci yaitu sebesar 13,09 $\mathrm{cm}$ kemudian diikuti perlakuan arang sekam sebesar $12,64 \mathrm{~cm}$, dan rerata panjang akar tanaman paling rendah adalah pasir tidak dicuci yaitu sebesar 10,01 cm. Ini menunjukkan perlakuan berbedaan jenis media mempunyai efek tidak berbeda terhadap panjang akar tanaman kailan. Substrat dalam masa pertanaman biasanya meningkatkan bahan organik dan aktivitas mikroorganisme, yang dimungkinkan meningkatkan kompetisi oksigen dalam lingkungan akar. Kompetisi tersebut menyebabkan akar mengikat substrat, agar mendapatkan suplai oksigen (Bonachela et al. 2010). Semakin tinggi suhu minimum nutrisi $\left(25^{\circ} \mathrm{C}\right)$, secara signifikan meningkatkan pertumbuhan tanaman karena meningkatnya fluks atas nutrisi dan air (Economakois dan Krulji 2001).

\section{Berat Brangkasan Segar Tanaman}

Berat tanaman merupakan parameter untuk menentukan hasil suatu budidaya tanaman. Berat segar per perlakuan diukur dengan cara menimbang setiap tanaman yang telah dipanen. Pada perlakuan jenis media, berat segar yang dicapai pada umur 10 MST berbeda. Dari tabel rerata berat segar (Tabel 5) dapat dilihat bahwa rerata perlakuan tertinggi adalah jenis media pasir tidak dicuci yaitu sebesar $6,7 \mathrm{~g}$ kemudian diikuti perlakuan media pasir dicuci sebesar $6,22 \mathrm{~g}$, dan rerata berat segar paling rendah adalah arang sekam yaitu sebesar $20,21 \mathrm{~g}$. Ini menunjukkan perlakuan berbedaan jenis media mempunyai efek berbeda terhadap berat segar kailan. Rerata berat brangkasan segar umur 10 MST disajikan pada Tabel 4.

Berdasarkan hasil penelitian, terlihat bahwa perlakuan jenis media menunjukkan pengaruh yang berbeda nyata terhadap bobot segar kailan. Terjadinya perbedaan yang nyata pada bobot segar kailan, diduga karena adanya perbedaan jumlah air yang terkandung di dalam tanaman. Jumlah air yang berbeda pada setiap tanaman dikarenakan berbedanya jenis campuran media yang digunakan pada tanaman. Perbedaan media dalam menyerap air nutrisi berpengaruh pada berat segar tanaman yang dikarenakan tersedia tidaknya air dan unsur hara dalam media tersebut. Pada campuran dengan pasir dicuci maupun tidak dicuci berat brangkasan tanaman lebih tinggi dibandingkan campuran arang sekam. Hal ini disebabkan serat dengan campuran dengan arang sekam mengalami pelapukan sehingga kemampuan serat dan aran sekam dalam menyediakan air dan unsur hara berkurang, pelapukan juga menyebabkan massa media menjadi menyusut sehingga tidak dapat menopang pertumbuhan akar dan tinggi tanaman. Setiap tanaman memiliki kemampuan untuk menyerap air tanaman (Irianto 2008). Kekurangan unsur hara terlihat karena unsur hara $P$ penting sebagai komponen struktural esensial ADP, ATP NAD, NADPH dan komponen informasi genetik DNA dan RNA. Fugsi unsur hara $P$ ada proses fisologis dan biokimia tanaman, yaitu mengaktifkan proses metabolisme tanaman, mengatur keseimbangan senyawa pengatur tumbuh endogen atau alami, mengatur pertisi dan translokasi fotosintat dan keseimbangan antara peti dan sukrose (Heldt et al. 1977). 
Tabel 4. Rerata berat brangkasan segar umur 10 MST pada beberapa perlakuan media

\begin{tabular}{lllll}
\hline \multirow{2}{*}{ Substrat } & \multicolumn{3}{c}{ Berat segar $(\mathrm{g})$} & \multirow{2}{*}{ Rerata } \\
\cline { 2 - 4 } & Pasir dicuci & Pasir tidak dicuci & Arang sekam & \\
\hline Rendam larutan fungisida & 3,89 & 6,13 & 2,23 & $4,08 \mathrm{a}$ \\
Sterilisasi autoklaf & 9,02 & 6,93 & 1,64 & $5,86 \mathrm{a}$ \\
Rendam air enam hari & 5,75 & 7,03 & 2,76 & $5,18 \mathrm{a}$ \\
\hline Rerata & $6,22 \mathrm{~b}$ & $6,7 \mathrm{~b}$ & $2,21 \mathrm{a}$ \\
\hline
\end{tabular}

Keterangan: Nilai yang diikuti huruf beda pada kolom atau baris yang sama menunjukkan berpengaruh nyata pada Uji DMRT taraf $5 \%$.

\section{Berat Brangkasan Kering Tanaman}

Berat tanaman merupakan parameter untuk menentukan hasil suatu budidaya tanaman. Dan berat kering per perlakuan diukur dengan cara menimbang setiap tanaman yang telah dioven selama dua hari. Berikut adalah diagram pengaruh perlakuan campuran media serat aren dengan jenis media terhadap berat kering saat panen.

Biomassa merupakan akumulasi fotosintat yang berupa protein, karbohidrat dan lipida (lemak).
Semakin besar biomassa suatu tanaman, maka kandungan hara yang terserap oleh tanaman juga besar. Biomassa tajuk merupakan akumulasi fotosintat yang berada di batang dan daun. Sitompul et al. (1995) menyatakan pengeringan bahan bertujuan untuk menghilangkan semua kandungan air bahan yang dilakukan pada suhu relatif tinggi selama jangka waktu tertentu hingga mencapai berat kering konstan. Biomassa pada umumnya digunakan sebagai petunjuk yang memberikan ciri pertumbuhan.

Tabel 5. Rerata berat brangkasan kering pada umur 10 MST pada beberapa perlakuan media

\begin{tabular}{lllll}
\hline \multirow{2}{*}{ Substrat } & \multicolumn{3}{c}{ Berat kering $(\mathrm{g})$} & \multirow{2}{*}{ Rerata } \\
\cline { 2 - 4 } & Pasir dicuci & Pasir tidak dicuci & Arang sekam & $0.47 \mathrm{a}$ \\
Rendam larutan fungisida & 0.45 & 0.71 & 0.25 & $0.72 \mathrm{a}$ \\
Sterilisasi autoklaf & 1.17 & 0.81 & 0.17 & $0.57 \mathrm{a}$ \\
Rendam air enam hari & 0.62 & 0.79 & 0.29 & \\
\hline Rerata & $0.75 \mathrm{~b}$ & $0.77 \mathrm{~b}$ & $0.24 \mathrm{a}$ & \\
\hline
\end{tabular}

Keterangan: Nilai yang diikuti huruf beda pada kolom atau baris yang sama menunjukkan berpengaruh nyata pada Uji DMRT taraf $5 \%$.

Berdasarkan Tabel 5 diketahui bahwa perlakuan pasir tidak dicuci memberikan hasil tertinggi terhadap biomassa kering tanaman yaitu sebesar 0,77 gram. Perlakuan arang sekam memberikan hasil terendah yaitu sebesar 0,24 gram. Hal ini diduga karena campuran padat aren dengan arang sekam tidak saling menopang. Arang sekam yang menyerap proses fotosintesis akan terhambat. Jika proses fotosintesis terhambat mengakibatkan fotosintat yangdihasilkan rendah dan berpengaruh terhadap biomassa kering tanaman. Tingginya suhu media juga mempengaruhi pertumbuhan tanaman, suhu mempengaruhi tanaman dalam dua cara. Temperatur yang tinggi cenderung untuk mempercepat pertumbuhan tanaman yang meningkatkan kebutuhan tanaman untuk air. Temperatur yang tinggi juga meningkatkan tanaman konsumsi air untuk pendinginan sendiri melalui penguapan (Mugundhan 2011). Penambahan bahan anorganik pada bahan organik menghasilkan hasil yang lebih tinggi, mungkin karena meningkatkan kapasitas menahan air dan aerasi oleh bahan organik, yang menunjukkan bahwa bahan anorganik bisa menggantikan sebagian bahan organik (Gao et al. 2010). panas menyebabkan pelapukan serat aren menjadi cepat sehingga fisik media berubah sehingga kemampuan media tidak berfungsi normal, oleh karena itu air nutrisi yang diberikan tidak dapat diserap oleh tanaman dengan sempurna. Air merupakan faktor penting dalam proses fotosintesis sehingga apabila tanaman kekurangan air maka

\section{KESIMPULAN DAN SARAN}

\section{Kesimpulan}

Berdasarkan hasil penelitian dapat diambil beberapa kesimpulan sebagai berikut:

1. Campuran antara serat aren dan jenis media tidak saling berinteraksi mempengaruhi semua variabel pengamatan.

2. Perlakuan rendaman serat aren hanya mempengaruhi jumlah daun tanaman. Rerata jumlah daun tanaman pada serat aren rendam fungisida sebesar 4,54 helai, serat aren sterilisasi 5,88 helai dan yang tertinggi pada rendam enam hari sebesar 6,25 helai.

3. Campuran serat aren dengan pasir dan arang sekam belum berpotensi sebagai media budidaya kailan. 


\section{Saran}

Saran yang diberikan dalam penelitian ini adalah sebagai berikut :

1. Diperlukan pengamatan mengenai kandungan unsur hara pada media serat aren yang lebih mendalam.

2. Diperlukan ragam perbandingan campuran media dengan serat aren.

3. Diperlukan pengamatan tentang kecepatan pelapukan media serat aren.

\section{DAFTAR PUSTAKA}

Alexander M. 1977. Introduction to Soil Microbiology. New York (NY): John Wiley and Sons.

Bilderback T. 2005. Substrates need physicals. Hort Technology 15: 747-751.

Bonachela S, Acuña RA, Magan JJ, Malfa O. 2010. Oxygen enrichment of nutrient solution of substrate-grown vegetable crops under mediterranean greenhouse conditions: oxygen content dynamics and crop response. Spanish $\mathrm{J}$ Agric Res 8(4): 1231-1241. (Dec 2010). ISSN: 1695-971-X.

Doorenbos J, Pruitt WO. 1979. Guidelines for crop water requirements. FAO Irrigation and Drainage. Paper. FAO, UN. Rome, Italy.

Firdayati M, Handajani M. 2005. Studi karakteristik dasar limbah industri tepung. J Infrastruktur dan Lingkungan Binaan. 1(2).

Gao HB, Zhang TJ, Lv GY, Zhang GH, Wu XL, Li JR, Gong BB. Effects of different compound substrates on growth, yield and fruit quality of cucumber // Acta Horticulturae. 2010. 856: 173-180.

Gardner FP, Pearce RB, Mitchell RL. 1991. Fisiologi tanaman budidaya. (diterjemahkan oleh $\mathrm{H}$ Susilo dan Subiyanto). Jakarta (ID): UI Press.
Haryanto ET, Suhartini, Rahayu E. 2001. Sawi dan selada. Jakarta (ID): PT. Penebar Swadaya.

Heldt HW, Chon CJ, Maronde D, Herold ZS. 1977. Role of phosphate and other factors in the regulation of starch formation in leaves and isolated chloroplast. J Plant Physiol 59: 1146-115.

Irianto. 2008. Pertumbuhan dan hasil kailan (Brassica albogabra) pada berbagai dosis limbah cair sayuran. J Agro 12(1), Januari - Juni (2008).

Lakitan B. 2004. Dasar-dasar fisiologi tumbuhan. Jakarta (ID): Rajagrafindo Persada.

Nair A, Ngouajio M, Biernbaum J. Alfalfa-based organic amendment in peat-compost growing medium for organic tomato transplant production. Hort Sci 2011. 46: 253-259.

Saleh MS, Fathurrahman. 2011. Pertumbuhan kecambah aren (Arenga pinnata wurmb.) merr dari pohon induk berbeda ketinggian dengan pemberian pupuk organik. J Agron Indonesia 39 (1) : 68-72.

Siregar HM. 2000. Upaya meningkatkan produktivitas pada budidaya tempuyung (Sonchus arvensis L.). J Gakuryoku 6 (2): 92-95.

Sitompul SM, Guritno B. 1995. Analisis pertumbuhan tanaman. Yogyakarta (ID): Gadjah Mada University Press. hal: 160-171.

Syarief R, Irawati A. 1988. Pengetahuan bahan untuk industri pertanian. Jakarta (ID): Mediyatama Sarana Perkasa.

Tyndall. 1986. Bertanam sawi. Jakarta (ID): Penebar Swadaya.

Tzortzakis NG, Economakis CD. 2008. Impacts of the substratemedium on tomato yield and fruit quality in soilless cultivation // Horticultural Science. 35: 83-89. 